Canadian Journal of Fisheries and Aquatic Sciences

Canadian Science Publishing

Journal canadien des sciences halieutiques et aquatiques

\title{
Can recovery from disturbance explain observed declines in total phosphorus in Precambrian Shield catchments?
}

\begin{tabular}{|r|l|}
\hline Journal: & Canadian Journal of Fisheries and Aquatic Sciences \\
\hline Manuscript ID & Cjfas-2015-0312.R1 \\
\hline Manuscript Type: & Article \\
\hline Date Submitted by the Author: & $25-$ Nov-2015 \\
\hline Complete List of Authors: & $\begin{array}{l}\text { Crossman, Jill; Trent University, Chemistry; Oxford University, OUCE } \\
\text { Eimers, M.; Trent University, } \\
\text { Watmough, Shaun; Trent University, } \\
\text { Futter, Martyn; Swedish University of Agricultural Sciences, Aquatic } \\
\text { Sciences and Assessment } \\
\text { Kerr, Jason; Alberta Monitoring, Evaluation and Reporting Agency, } \\
\text { Baker, Scott; Trent University, } \\
\text { Dillon, Peter; Trent University }\end{array}$ \\
\hline Keyword: & $\begin{array}{l}\text { PHOSPHORUS < General, LAKES < Environment/Habitat, WETLANDS < } \\
\text { Environment/Habitat, RIPARIAN < Environment/Habitat, STREAMS < } \\
\text { Environment/Habitat }\end{array}$ \\
\hline &
\end{tabular}



KERR $^{6}$, SCOTT R BAKER ${ }^{4}$, and PETER J DILLON ${ }^{1}$

${ }^{1}$ Chemistry Department, Trent University, Peterborough, Ontario. ON K9J 7B8

${ }^{2}$ Oxford University Centre for the Environment, Oxford University, Oxford. UK. OX1 3QY

$7 \quad{ }^{3}$ Department of Geography, Trent University, Peterborough, Ontario. ON K9J 7B8

$8 \quad{ }^{4}$ Environmental and Resource Studies Program, Trent University, Peterborough, ON K9J 7B8

$9{ }^{5}$ Department of Aquatic Sciences and Assessment, Swedish University of Agricultural Sciences, Uppsala, Sweden

${ }^{6}$ Alberta Environmental Monitoring, Evaluation and Reporting Agency, Calgary AB T2E 7L7

\section{Abstract}

The plausibility of land disturbance as a cause of declining P concentrations in oligotrophic lakes within south-central Ontario, Canada is evaluated using the process-based model INCA-P. The model was calibrated upon three catchments in the Muskoka-Haliburton region (MHR): Harp (HP), Dickie (DE) and Plastic (PC), which have varying degrees of declining P export, and different forms of historic disturbances (timber harvesting, tree-death, and soil acidification respectively). Hind-casts (1978-2007) were run with and without simulated disturbances. Model performance of both DE and HP was greatly improved when effects of wetland tree deaths (DE) and harvesting (HP) were included. In PC, with no record of timber harvesting and relatively minor declines in P, initial hindcasts successfully accounted for the majority of inter-annual P-fluxes; and performance was only marginally improved through the simulation of soil acidification. Vegetation decay, harvesting and catchment acidification accounted for $63 \%, 24 \%$ and $0.6 \%$ of $P$ export over the past 30 years respectively. Of all disturbances, wetland vegetation death had the highest impact on areal P exports, indicating that riparian stability is particularly important. 


\section{Introduction}

Phosphorus (P) is an essential nutrient (Sharpley et al. 2013) which can limit aquatic productivity

(Jeppesen et al. 2005). In the predominantly oligotrophic lakes of the Precambrian Shield landscape in south-central Ontario, declines in stream and lake P concentrations over the past 30 years (since 1976) have been linked to an increase in dominance of odorous algae (chyrosophytes) (Paterson et al. 2004) and are now a critical concern (Palmer et al. 2011). Understanding the cause of the P decline, and predicting how P concentrations in this landscape may change in the future, is essential to lake management. To date, it has been established that changes in flow alone cannot account for P declines, as alterations in annual and seasonal discharge have been insignificant (O'Brien et al. 2013). Exhaustion of mineral supplies is also an implausible explanation, as this area has relatively "young" soils (Kirkwood and Nesbitt 1991).

It has been suggested that a more likely explanation for regional long term changes in $\mathrm{P}$ concentrations is disturbance events, such as timber harvesting and wetland disturbance, which can lead to an increase in P export from soils due to higher P mobility (Eimers et al. 2009; O’Brien et al. 2013; Pinder et al. 2014; Baker et al. 2015). These disturbances are thought to have caused elevated P exports prior to the 1980s, with subsequent declines representing a return to pre-disturbance conditions (Eimers et al. 2009). Proposed "disturbance" mechanisms include changes in soil conditions and vegetation health, associated with tree felling or death, and catchment acidification, which are both regional and likely to have occurred around a relevant time period (Jeziorski et al.

47 2008; Watmough and Dillon 2003a). to increases in P mobility (Jarvie et al. 2013). Tree death in this predominately forested landscape, 
characterised by granitic soils with low $\mathrm{P}$ weathering rates, can therefore contribute significant

quantities of $P$ to streams through decaying biomass (Pinder et al. 2014; Knops et al. 2010). Further,

the effect of forest disturbance can be more pronounced in riparian areas or wetlands that are more strongly hydrologically connected to surface waters. Following the initial disturbance event, P inputs decline over time as the majority of nutrients are released during earlier stages of decay (Fahey et al. 1991; Knops et al. 2010). This decline is heightened by high $P$ uptake rates of young vegetation as it re-establishes (Jorgensen et al. 1975), which acts to limit the soil P concentrations, increase the availability of soil P binding sites, and to gradually reduce P mobility. Removal of vegetation e.g. by selective tree harvesting, has also been associated with increased P mobility, linked with reduced uptake of nutrients (Piirainen et al. 2004) and an increased supply of organic and inorganic anions which compete with P for sorption sites (Väänänen et al. 2007).

Soils within south-central Ontario have also been subject to acidification, due to atmospheric deposition of $\mathrm{H}_{2} \mathrm{SO}_{4}$ and $\mathrm{HNO}_{3}$. In soils with a relatively low $\mathrm{pH}$, such as those overlying the Precambrian Shield, it has been suggested that sulphate $\left(\mathrm{SO}_{4}{ }^{2-}\right)$ has a significant influence on $\mathrm{P}$ sorption, where competition between $\mathrm{SO}_{4}{ }^{2-}$ and $\mathrm{P}$ leads to lower $\mathrm{P}$ retention (Geelhoed et al. 1997; Baker et al. 2015). It is unlikely that $\mathrm{SO}_{4}{ }^{2-}$ has been the sole cause of $\mathrm{P}$ alterations at all sites, given a weak correlation between $\mathrm{SO}_{4}{ }^{2-}$ and $\mathrm{P}$ (Eimers et al. 2009), and the large differences in rates of $\mathrm{P}$ declines between catchments. It may, however, be a contributing factor in catchments which have been extensively acidified (Baker 2014).

There remains a substantial amount of uncertainty surrounding the causes of $\mathrm{P}$ declines, and the impact of catchment disturbance. Process-based models, such as the spatially distributed model INCA-P, can help to provide additional insight, through facilitating integration of site-specific observed data over the subcatchment scale, defining dominant drivers of catchment P-transport mechanisms, and ultimately highlighting appropriate management strategies (Sharpley et al. 2002). 
and Plastic (PC), which have undergone varying degrees of $\mathrm{P}$ decline, and different forms and degrees of historic disturbance (vegetation-death, timber harvesting, and extensive soil acidification respectively). The aim is to determine whether these disturbance events can account for declines in

P exports within the study sites, and if so whether catchments have returned to pre-disturbance conditions, or if further declines in P might be anticipated. The models are calibrated during a period of low disturbance (2000-2007), and hind-casts run from 1978-2007. Hind-casts are run both with and without the inclusion of simulated disturbances, and changes in total phosphorus (TP) loads which may be attributed to historic disturbance events are then quantified.

\section{Methods}

\subsection{Site description}

All three catchments (Figure 1) are located in the Precambrian Shield landscape of south-central

Ontario, in the Muskoka-Haliburton region (MHR). The geology of the area is characterised by impermeable Precambrian silicate bedrock (Dillon and Molot 2005) covered with thin basal tills which in DE and PC are predominantly less than $1 \mathrm{~m}$ thick. In HP, tills may reach up to $4 \mathrm{~m}$ in upland reaches (Watmough and Dillon 2003a). Owing to the thin coverage by overlying soils in the MHR, ridges are characterised by exposed bedrock, and organic soils are found in wetland areas (covering 9.3\%, $10 \%$ and $1.6 \%$ of DE, HP and PC respectively). HP has the largest catchment area (542ha), supporting the deepest lake of the study sites $(13.3 \mathrm{~m})$. DE has a smaller catchment area (500 ha), but larger lake surface area (93.6ha), and is substantially shallower (5m deep). Finally, PC is the smallest of the study catchments (127ha), with the smallest lake surface area (32.1ha), and an intermediate depth $(7.9 \mathrm{~m})$. The catchments vary in their extent of residential and road development, with the greatest amount of shoreline housing found in DE (125 houses), followed by HP ( 83 houses)

97 (Dillon and Molot, 1996). There is no residential development within PC (Table 1). Vegetation in the upland forests of HP and DE is similar; predominantly composed of sugar maple (Acer saccharum) and yellow birch (Betula alleghaniensis) (O'Brien et al. 2013; Pinder et al. 2014). Eastern cedar (Thuja 
occidentalis) and eastern hemlock (Tsuga canadensis) may also be found in wetland areas, along

with black spruce (Picea mariana) in DE. PC predominantly supports white pine (Pinus strobus), eastern hemlock and red maple (Acer rubrum; Watmough and Dillon 2003b).

Disturbances to vegetation have been reported at DE and HP. In DE, areas of dead trees in forested wetlands affects up to $52 \%$ of riparian areas in some sub-catchments (Pinder et al. 2014). The widespread death of trees in the wetlands has been attributed to a rise in water table, possibly caused by road construction around the lake in the mid 1970's (Pinder et al. 2014). In HP, selection timber harvesting (predominantly carried out prior to 1983), has resulted in reduced tree density within forest biomass since 1983 (Watmough and Dillon 2003b).

The temperate climate of the three study sites, located within a $30 \mathrm{~km}$ radius, was similar during the period of record (1978-2007). The catchment average annual temperature was $5.1^{\circ} \mathrm{C}$, ranging by less than $0.3^{\circ} \mathrm{C}$ between sites. Average annual precipitation was $1012 \mathrm{~mm}$, differing by less than $12.8 \mathrm{~mm}$ between sites. Snowfall and seasonal freezing of the lakes was usual in winter (December - February), with an average temperature of $-8.4^{\circ} \mathrm{C}$. Spring melt occurred in March - May, with an average temperature of $4.4^{\circ} \mathrm{C}$.

\subsection{INCA-P Model Calibration}

120 INCA-P (v.1.2.1) is a process-based, spatially distributed model, and was chosen for its focus on

121 representing the underlying physical processes that describe system behaviour (Adams et al. 2013;

122 Crossman et al. 2014). The model has been applied to over 40 catchments worldwide, and uses a semi-distributed approach to simulate the daily transport of a variety of water quality variables 
124 (including sediments, water and nutrients) in both the terrestrial and the aquatic phase (Whitehead 125 et al. 2011). Simulation of terrestrial processes may be differentiated into an arbitrary number of 126 land cover or landuse types. As a fully branched model, INCA can provide soil export coefficients 127 and daily simulations of stream flow, sediment mass and P concentrations (dissolved DP, particulate 128 PP and total TP) for an unlimited number of tributaries, subcatchments and stream orders.

INCA-P requires a daily input time series of precipitation, temperature, hydrologically effective rainfall (HER) and soil moisture deficit (SMD). Whilst precipitation and temperature were obtained from local climate stations (DESC 2012a), HER and SMD were derived from the rainfall-runoff model Nordic HBV (Hydrologiska Byråns Vattenbalansavdelningen) (Saelthun 1995). An individual HBV and associated INCA model set-up was used for each study catchment. The INCA model applications were calibrated following procedures outlined in Crossman et al. (2014), whereby plausibility of calibration values was assessed through a variety of methods including field measurements, GIS and digital elevation assessments, literature values, and model performance statistics. A calibration period from 2000-2007 was initially selected for each catchment, during which time there were fewer reported periods of disturbance (Pinder et al. 2014; Watmough and Dillon 2003a). Intensive monitoring within each catchment over these 8 years facilitated the detailed calibration of INCA-P within multiple subcatchments at each study site.

141 A hydrological network for each study catchment was developed from a digital elevation model, using ArcHydro GIS software. Land use was derived from the Ecological Land Classifications of Ontario data (Ontario Ministry of Natural Resources 2007; adapted by O'Connor et al. 2009), and grouped into five cover classes; cottage developments ("residential"), wetland, coniferous forest, deciduous forest and open water. Within DE and HP, nutrient input rates from cottage septic tanks (0.86 kg P/ha/year in DE, and 1.6kg P/ha/year in HP) were calculated using methods in Dillon and Molot (1996), and applied at a daily rate to the residential landuse sites throughout the summer. Total P input rates from wetlands, coniferous and deciduous forests were calculated at 
$0.88 \mathrm{~kg} / \mathrm{ha} /$ year, $1.18 \mathrm{~kg} / \mathrm{ha} /$ year and $0.71 \mathrm{~kg} / \mathrm{ha} /$ year within $\mathrm{DE}, \mathrm{HP}$ and $\mathrm{PC}$ respectively, using data from Dillon and Molot (1996). Previous studies indicate that the amount of P lost from wetland ecosystems can exceed twice that of forested watersheds (Richardson 1985) and thus 70\% of the daily vegetative total was assigned to wetlands, with the remaining $30 \%$ split equally between coniferous and deciduous forests.

A three-station average of regional atmospheric P deposition data was available from 1976-2007, with daily measurements taken at HP, PC and Heney (adjacent to DE) (DESC 2012b). Atmospheric deposition was input into each model as a daily time series (averaging $0.4 \mathrm{~g} / \mathrm{ha} / \mathrm{day}$ ). As bulk collectors also collect pollen and other organics, net atmospheric P deposition at the 3 sites may have been overestimated by as much as $40 \%$. A conservative adjustment of atmospheric inputs to the terrestrial watershed was therefore carried out ( $25 \%$ reduction), given that the exact impact of pollen on the atmospheric $\mathrm{P}$ records has not yet been established. Atmospheric inputs to the lakes were not altered, as these organic inputs are considered part of the lake P-load. Initial soil P concentrations were based on values measured by Baker (2014), and soil equilibrium coefficients based on laboratory derived equilibrium $\mathrm{P}$ concentrations $\left(\mathrm{EPC}_{0}\right)$ and Freundlich isotherm values for different soil and land use types (Peltovuori 2006; Väänänen 2008; Koski-Vähälä 2001).

\subsubsection{Inclusion of "disturbance" within INCA model}

In order to test whether disturbance could explain observed historical changes in stream TP at the three catchments, a sixth landuse class, "disturbance", was input to the model as an annual time series, with model rates of land-use change calibrated to match observed in-stream TP concentrations, and historic disturbance reports (e.g. Watmough and Dillon 2003a). In every model, calibration of the disturbance class was based upon values from an existing land cover category

171 ("wetlands" in DE, and "forest" in HP and PC), to which changes were made based upon field 172 measurements and existing literature (Pinder et al. 2014; Watmough and Dillon 2003a, 2003b)

173 (Table 2). The disturbance classes of all models contained reduced plant uptake, either to simulate 
174 lower vegetation density (DE and HP), or declines in vegetation health (PC). Additional P inputs to

175 the soil were added only to the DE disturbance class (163kg over 30 years), simulating vegetation

176 decay over time, based upon measurements from Pinder et al (2014). In HP, it was assumed that

177 selective timber harvesting resulted in the majority of disturbed vegetation being removed from the

178 site. To replicate changes to P mobility, all disturbance classes also contained elevated equilibrium $\mathrm{P}$

179 concentrations $\left(\mathrm{EPC}_{0}\right)$. As the $\mathrm{EPC}_{0}$ rises, soil adsorption generally becomes increasingly difficult

180 (Shafqat and Pierzynski 2014). Thus, within INCA v1.2.1 the effects of both reduced P sorption sites

181 under excess P additions (Nzigheba et al. 1998; Jarvie 2013), and of increased competition with

182 anions associated with harvesting and acidification (Giesler et al. 2005; Geelhoed et al. 1997), may

183 be simulated by increasing soil EPC $\mathrm{E}_{0}$ values (Table 2). Whilst all disturbance classes were slightly

184 different, they were based upon a similar theory of simulating changes to soil properties in areas

185 historically characterised by high P mobility, to those currently characterised by lower P mobility.

186 3. Results

\subsection{Model Performance}

\subsubsection{INCA calibration performance}

Model outputs from all catchment inflows and lake outflows were compared with observed flow data and grab samples of TP (DESC 2012c). Over the calibration period (2000-2007), the model was successful in representing seasonal fluxes within each catchment with an average catchment $R^{2}$ of over 0.9 for stream flow at each site, between 0.5 and 0.7 for TP concentration, and between 0.6 and 0.7 for TP load (Figure 2a). Simulation of inter-annual trends $\left(R^{2}\right)$ was however less successful (Figure 2a), although total model error (\%) was similar to that of seasonal performance (Figure 2b). period of low disturbance (2000-2007) were unable to entirely account for observed long-term changes in TP loads. This issue was even more apparent when the model was applied over the 
complete period of record (1978-2007). The INCA model failed to reproduce the observed large historic changes in TP concentrations in both DE and HP (Figure 3), but was more successful in PC where changes in TP loads have been lower. It was evident, therefore, that additional drivers (e.g. disturbance) were required to explain P declines.

\subsubsection{Model hindcast performance}

The inclusion of disturbance parameters greatly improved inter-annual model performance $\left(R^{2}\right)$ in TP concentrations and loads from 1978-2007 at all sites (Figures 4a and 5). Model performance of discharge was unchanged (not shown), though total model error (\%) for TP concentration was closer to 0 within all catchments (Figure $4 \mathrm{~b}$ ). Improvements were greatest in DE and HP, where larger scale anthropogenic events have been reported. At DE and HP INCA simulated reductions in average annual stream TP concentrations from 50 and $20 \mu \mathrm{g} / \mathrm{l}$ in the early 1980 's, to values of 20 and $10 \mu \mathrm{g} / \mathrm{l}$ by 2007 respectively, with an average annual reduction in TP load of $6 \%$ and $4 \%$. Although INCA simulated a reduction in annual stream flow over this period, at a rate of less than $1 \%$ per year, the decline in flow could not account for the modelled alterations in P exports (Figure 3).

Even in PC, where anthropogenic influences were low, the addition of disturbance drivers into the model increased performance statistics. Here, simulated long term changes in annual P fluxes were smaller than at DE and HP by an order of magnitude, with a total change in annual TP concentrations of only $1 \mu \mathrm{g} / \mathrm{l}$ over the 30 years (a change greater than the calculated model error of $8.2 \%$; or $0.73 \mu \mathrm{g} / \mathrm{l})$, and an average annual reduction in TP load of only $0.4 \%$. In this catchment, the smaller inter-annual P variability can in part be explained by changes in flow (Figure 3). The model performance improvements achieved by inclusion of the disturbance parameters indicate that vegetation decay, forest harvesting and acidification as simulated by INCA-P have all had some influence on long-term $\mathrm{P}$ export at DE, HP and PC respectively. As the models successfully reproduced observed long-term P-fluxes $\left(R^{2}\right)$, the difference in exports between the two hindcasts 
222 (with and without disturbance) can be used to quantify the proportion of change in $\mathrm{P}$ that might be 223 attributed to disturbance events.

\subsection{Quantification of disturbance contributions using INCA-P}

Source apportionment calculations revealed that within DE and HP, simulated P-outputs from residential, forest and wetland soils remained relatively stable over the hindcast period, and exports from disturbed areas accounted for a large proportion of the observed P declines (Figure 6). Over the hindcast period, dead/decaying forest yielded the greatest $\mathrm{P}$ release $(3.8 \mathrm{~kg} / \mathrm{ha} / \mathrm{year})$, compared with forest harvesting $(0.31 \mathrm{~kg} / \mathrm{ha} /$ year $)$ and soil acidification $(0.002 \mathrm{~kg} / \mathrm{ha} /$ year). The total P exports from the DE and HP inflow catchments were calculated at $1626 \mathrm{~kg}$ and $1259 \mathrm{~kg}$ respectively. Of this, $63 \%(1025 \mathrm{~kg})$ can be traced back to disturbance events within DE, and $24 \%(297 \mathrm{~kg})$ within HP. In the $P C$ catchment, disturbance accounted for just $0.6 \%$ of $P$ exports $(0.14 \mathrm{~kg})$. At this site, much of the inter-annual variability in P outputs corresponds with meteorological fluxes (Figure 6). Importantly, the results suggest that not all catchments have returned to pre-disturbance conditions, with $1.2 \%$ of DE P exports in 2007 continuing to be attributable to the disturbance effect. Until this site has fully recovered, further "declines" in P may be anticipated.

Using INCA modelled values, and based upon the methods of Eimers et al. (2009) the average annual percent TP retention (\%TPR) over the 1978-2007 period was calculated for each catchment, and for the lakes. Inputs incorporated within these calculations include subsurface flow, atmospheric $P$ deposition, septic additions and vegetation decay, as it has been demonstrated that retention can be underestimated by up to $23 \%$ when these are not considered (Dillon and Molot 1996). Over this period, \%TPR retention was highest in HP and PC (Figure 7), suggesting these two sites have a higher capacity to adsorb P. In DE, \%TPR was notably negative in all inflow catchments, indicating high mobility of $\mathrm{P}$ which may help to explain the higher annual exports from this catchment (Figure 6). Positive retention values were estimated within DE lake itself however (Table 3), indicating that some of the P exported from the DE inflows may be stored within lake sediments. Lake \%TPR varied 
247 seasonally, and was lowest at all sites in spring and autumn, and highest during winter and summer

248 (Table 3). Seasonal variation was greatest within the DE catchment.

249

250

\subsection{Model simulation of stream and lake nutrient dynamics}

Modelled discharges were greatest in both catchment inflows and lake outflows during spring, declining rapidly to a seasonal low occurring in late summer (July in DE and PC; August in HP). Within DE, the TP concentrations of inflow streams were much higher than those of lake outflows. Inflow and outflow concentrations in HP were more similar, and in PC were marginally higher in outflows. In HP and PC, stream discharge and stream TP concentrations were negatively associated throughout the year. This relationship was strongest during winter and autumn ( $R^{2}=0.8$ to 0.99$)$. Inflowing TP concentrations peaked during summer low flow periods, with seasonal highs during later summer and early autumn. Seasonal fluxes varied within individual streams, with HP 3a and HP 4 showing additional peaks in TP concentration during the spring melt period. In contrast, within DE inflows, TP concentrations were positively correlated with flow throughout winter, spring and autumn $\left(R^{2}=0.9\right.$ to 0.98$)$. Here, TP concentrations peaked during high flow periods, with highest concentrations during spring, followed by a seasonal low in early summer, and a steady rise throughout the season to a second smaller peak in late autumn.

\section{Discussion:}

The INCA model indicates that within the DE and HP catchments, inter-annual variability in precipitation and TP deposition, and a $1 \%$ annual reduction in flow, are all insufficient to account for the large observed decreases in TP loads at these catchments (4-6\%). The inclusion of a disturbance class within INCA was necessary to simulate past changes in catchment export and lake TP concentrations. Disturbance events are believed to elevate soil P mobility, resulting in higher stream and lake TP concentrations, which gradually return to "pre-disturbance" conditions. The assumption that disturbances impacted P export in this region is based on current measurements (e.g. standing 
271 dead trees, logging residues), as monitoring began subsequent to the events which occurred more

272 than 30 years ago. The possibility that $P$ declines may represent the tail-end of a historic phase of

273 raised $\mathrm{P}$ exports emphasises the dependence of perceived long-term change on the selection of

274 analysis period (Hartmann et al. 2013).

275 Model results indicated that disturbance events such as vegetation decay and selective timber

276 harvesting of forests have had the greatest impact on soil P mobility, and can account for between

$27763 \%$ and $24 \%$ of P exports within DE and HP respectively, over the 30 year period of record. Decaying

278 forests yielded the greatest $P$ release per hectare of disturbed land cover $(3.8 \mathrm{~kg} / \mathrm{ha})$, compared with

279 selective harvesting $(0.31 \mathrm{~kg} / \mathrm{ha})$. Acidification has had a much lower impact on surface water TP,

280 releasing only $0.002 \mathrm{~kg} \mathrm{P} / \mathrm{ha}$, though it may still be cause for concern, as $0.6 \%$ of exports over the

281 past 30 years can be attributed to this form of disturbance within the PC catchment. Importantly,

282 percentage $\mathrm{P}$ retention values (\%TPR) indicate that following disturbance, the DE catchment had a

283 much lower sorption capacity than either HP or PC (average of $-69.2 \%$ in DE compared to +59.0 and

$284+85.4 \%$ in $\mathrm{HP}$ and $\mathrm{PC}$ ). Low retention values within $\mathrm{DE}$ may be a result of the large quantities of $\mathrm{P}$

285 that were added to the catchment during tree death (up to $219 \mathrm{~kg}$ P from standing deadwood alone;

286 Pinder et al. 2014), which increase competition for soil sorption sites; and are consistent with

287 disturbed conditions (Väänänen et al. 2007; Ardon et al. 2010).

288 At DE, the positive relationship between precipitation, flow and in-stream TP concentrations is

289 further indicative of high P mobility. In areas with elevated soil P concentrations and associated low

290 P sorption capacity (like disturbed soils with decaying vegetation), P may be readily desorbed into

291 solution during precipitation events or saturated conditions (Haygarth et al. 1998; Borling 2003).

292 Where these areas are located close to watercourses, like wetlands, this P may be transported to

293 streams. During periods of surface erosion such as spring melt, P may also be delivered directly to

294 the streams on soil particles (Heathwaite and Dils 2000). These positive relationships (and

295 negative \%TPR values) indicate that the catchment is vulnerable to P-flushing events during wet 
periods. Results suggest that the DE catchment has recovered substantially since disturbance events in the 1970 s, however up to $1.2 \%$ of total annual P continues to be exported by disturbed sites, and thus further declines may be expected. Whilst the additional P inputs from decaying biomass clearly extended the required recovery period in the DE catchment, the higher impact of disturbance within wetland areas may also in part be associated with the proximity of disturbance to catchment inflows. Disturbances in DE were reported within riparian wetlands, where any change in P exports would be more directly relayed to the water course; and previous studies have indicated (e.g. Devito et al. 2000) that the impacts of disturbance on streams are likely to be greatest where the terrestrial and aquatic environment are directly hydrologically connected. Finally, whilst the model demonstrates that that changes in hydrology alone are insufficient to account for observed reductions in P export, a change in hydrological connectivity could have contributed to the impact of disturbance. As the disturbance in $\mathrm{DE}$ is thought to originate from an elevated water table caused by road building, connectivity would be higher shortly following the initial disturbance period; and would decline thereafter as vegetation regrowth re-established root systems (Moore and Wondzell 2005).

Within HP and PC, where smaller impact disturbance events were recorded, TP retention was higher. At these sites, P was not directly added through disturbance (i.e. the majority of the harvested tree biomass was removed), and effects were limited to indirect $P$ additions through changes to vegetation health (reduced $\mathrm{P}$ uptake) and greater competition for soil sorption sites (Giesler et al. 2005; Geelhoed et al. 1997). Negative relationships depicted at HP and PC between precipitation, flow and instream TP concentrations are indicative of lower P mobility, where greater quantities of $\mathrm{P}$ are adsorbed from throughflow during high flow periods, and released during low flow (e.g. via redox, where low stream flows and high temperatures lead to anoxia, reduction of $\mathrm{Fe}^{3+}$, and $\mathrm{P}$ release; O'Brien et al. 2013). Spring peaks in stream TP concentrations at HP3a and 4 could be associated with the proximity of harvested forests to riparian zones in these subcatchments. Here, a spring flush of $\mathrm{P}$ from soils with elevated $\mathrm{P}$ mobility (due to reduced nutrient uptake and an increased supply of organic and inorganic anions, Väänänen et al. 2007) may more directly enter the 
322 watercourse. At both PC and HP, results indicate that disturbance-related P contributions have now 323 ceased.

324 The differences in timing of seasonal TP fluxes between streams and the lakes can be attributed to seasonal variability in lake water residence times and \%TPR. The latter was highest in all sites during summer, decreasing through to winter. This may explain the steady decline in lake outflow TP concentrations from summer to early autumn within Dickie lake, which contrasts with those of stream inflows. In addition during both winter and spring, soil erosion carries P-rich sediments to the lake, which due to low TP retention in colder seasons, is likely to be conveyed more directly to the outflow (Dillon and Molot 1996).The lower P-content of sediments carried to HP and PC lakes, in addition to the lower seasonal variability of lake \%TPR, could explain the greater similarity in TP concentrations between stream and lake outflow concentrations at these sites.

Whilst further declines in P are unlikely at the now-stabilised PC site, additional P reductions might be expected within DE as wetland vegetation continues to recover. Here, although P exports to the lake have decreased, and lake sediments can adsorb some of the fluxes, elevated P mobility persists in 2007 , with $1.2 \%$ of P exports attributed to disturbance. Soils in DE currently have a lower capacity to retain added $\mathrm{P}$, and therefore subcatchments remain vulnerable to future disturbance. Furthermore, research indicates that although future soil acidification is unlikely in undisturbed areas (due to large decreases in S deposition), it may continue in harvested sites (Watmough and Aherne 2008); thus although P exports from disturbance in HP had ceased by 2007, this site may begin to experience future small $\mathrm{P}$ declines related to decreasing soil $\mathrm{pH}$. This study indicates that disturbance is less extensive, catchments may remain more resilient, e.g. PC. 
347 Modelling is emerging as an important tool in predicting the impacts of management strategies

348 (Baulch et al. 2013) and evaluation of land use scenarios (Oni et al. 2015). The ability of INCA to

349 simulate highly variable $\mathrm{P}$ exports under disturbed conditions indicates that this process-based

350 model could be particularly suitable for management applications within the MHR. Future research

351 could look to identify sustainable practices under which stable P exports are maintained, and to

352 determine how changes in climate may impact catchment sensitivity to landuse developments.

This study demonstrates that recorded declines in P concentrations and loads within streams and

lakes of the MHR may represent the return of systems to a steady-state, following disturbance events that occurred prior to initiation of monitoring programs, over 30 years previous. The INCA model indicates that death and decay of riparian wetland vegetation, and removal of trees through selective harvesting can account for 63 and $24 \%$ of $P$ exports respectively, between 1978 and 2007. In areas where no anthropogenic vegetation removal is recorded, smaller declines in inter-annual P loads were recorded, which were predominantly associated with changes in meteorology, atmospheric deposition and flow. Here, effects of soil acidification accounted for only $0.6 \%$ of the $P$ export.

The model results demonstrate that export of $\mathrm{P}$ from disturbed areas can be attributed at all sites to reduced vegetation uptake, higher soil mobility (i.e. reduced capacity to adsorb P due predominantly to an increased availability of competing anions), and additionally, at DE, to the direct addition of $P$ from decaying vegetation. Disturbance of wetlands in the DE catchment had significantly more impact on P export (3.8kg/ha) than disturbance of forests in the HP sites $(0.31 \mathrm{~kg} / \mathrm{ha})$ or soil acidification in PC $(0.002 \mathrm{~kg} / \mathrm{ha})$. Results suggest that whilst HP and PC have now returned to predisturbance conditions, DE continues to export $1.2 \%$ of $\mathrm{P}$ from disturbed areas. The greater impact of wetland disturbance, along with a longer recovery period required for disturbance in DE was attributed in part to the additional $\mathrm{P}$ inputs from decaying vegetation, and in part to the proximity of

371 these wetlands to the rivers. As the soil capacity to adsorb P within DE remains low, the study 
372 indicates that despite rapid vegetation regrowth, disturbance may leave behind a legacy of

373 vulnerability, rendering extensively disturbed sites more sensitive to future changes in both

374 meteorology and landuse. Those catchments where disturbance was less extensive, or had a lesser

375 impact (HP and PC), may harbour greater resilience. In summary, the study demonstrates the long-

376 term impacts of disturbing vegetation on P-exports, and the significant recovery periods required to

377 achieve nutrient stability once vegetation health is compromised, particularly for riparian wetland

378 areas.

Acknowledgements:

The authors would like to thank Daniel Butterfield, for his invaluable technical support throughout the project. Thanks also to Drs Huaxia Yao and Andrew Paterson and Lorna Murison for providing access to DESC records. Funding for this research was provided through a Canadian Water Network grant titled "Managing cumulative effects in the Muskoka River Watershed: monitoring research and predictive modelling", and an NSERC Postdoctoral Research Fellowship. The authors also thank Judi Brouse from the District of Muskoka for facilitating the study and leading the Muskoka Watershed Node, and Isobel Heathcote for providing site-specific information. Finally, thanks to Kieran Pinder for his insights into phosphorus release from forested wetlands.

References:

Adams, H. D., Williams, A. P., Chonggang, X., Rauscher, S. A.,Jiang, X., and McDowell, N. G. 2013.

Ardon, M., Montanari, S., Morse, J.L., Doyle, M.W., Bernhardt, E.S. 2010. Phosphorus export from a restored wetland ecosystem in response to natural and experimental hydrological fluctuations. Journal of Geophysical Research 115: 1-12 doi: 10.1029/2009JG001169 
395

396

Baker, S.R. 2014. Phosphorus forms and response to changes in $\mathrm{pH}$ in sensitive soils on the Precambrian Shield. PhD Thesis. Trent University. Peterborough, Ontario, Canada.

Baker, S.R., Watmough, S.A., and Eimers, M.C. 2015. Phosphorus forms and response to changes in pH in sensitive soils on the Precambrian Shield. Canadian Journal of Soil Science 95: 95-108

Baulch, H.M., Futter, M.N., Jin, L., Whitehead, P.G., Woods, D.T., Dillon, P.J., Butterfield, D.A., Oni, S.K., Aspden, L.P., O'Connor, E.M., and Crossman, J. 2013. Phosphorus dynamics across intensively monitored subcatchments in the Beaver River. Inland Waters 3: 187 - 206

Borling, K. 2003. Effects of long-term inorganic fertilisation of cultivated soils, Doctoral Thesis, Swedish University of Agricultural Sciences, Uppsala.

Crossman, J., Futter, M.N., Whitehead, P.G., Stainsby, E., Baulch, H.M., Jin, L., Oni, S.K., Wilby, R.L., and Dillon, P.J. 2014. Flow pathways and nutrient transport mechanisms drive hydrochemical sensitivity to climate change across catchments with different geology and topography Hydrology and Earth System Sciences 18: 5125 - 5148 doi: 10.5194/hess-18$5125-2014$

DESC (Dorset Environmental Science Centre). 2012a. Local daily observed meteorological records for Harp (45 22' $\left.7907^{\prime}\right)$, Plastic (45 11' 78 49') and Heney (45 07' $\left.7906^{\prime}\right)$ catchments. Available for download at www.desc.ca/data

DESC (Dorset Environmental Science Centre). 2012b. Observed atmospheric P deposition (3-station annual average). Available for download at www.desc.ca/data. Last accessed on April $1^{\text {st }}$ 2015.

DESC (Dorset Environmental Science Centre). 2012c. Observed water chemistry (grab sample data). Available for download at www.desc.ca/data. Last accessed on April $1^{\text {st }} 2015$. 
417 Devito, J.J., Creed, I.F., Rothwell, R.L., and Prepas, E.E. 2000. Landscape controls on phosphorus 418 loading to boreal lakes: implications for the potential impacts of forest harvesting. Canadian 419 Journal of Fisheries and Aquatic Sciences 87: 1977 - 1984 doi: 10.1139/f00-148

420

421

422

423

Dillon, P.J., and Molot, L.A. 1996. Long-term phosphorus budgets and an examination of a steadystate mass balance model for central Ontario lakes. Water Resources 10: 2273 - 2280 doi: $10.1016 / 0043-1354(96) 00110-8$

Dillon, P.J. and Molot, L.A. 1997. Effect of landscape form on export of dissolved organic carbon, iron and phosphorus from forested stream catchments. Water resources research. 33 (11) 2591 2600

Dillon, P.J., and Molot, L.A. 2005. Long-term trends in catchment export and lake retention of dissolved organic carbon, dissolved organic nitrogen, total iron and total phosphorus: The Dorset, Ontario, study, 1978-1998. Journal of Geophysical Research 110: 1 - 7 doi:10.1029/2004JG000003

Eimers, M.C., Watmough, S.A., Paterson, A.M., Dillon, P.J., and Yao, H. 2009. Long-term declines in phosphorus export from forested catchments in south-central Ontario. Canadian Journal of Fisheries and Aquatic Sciences 66: 1682 - 1692 doi: 10.1139/F09-101

Fahey, T.J., Stevens, P.A., Hornung, M., and Rowland, P. 1991. Decomposition and nutrient release from logging residue following conventional harvest of Sitka Spruce in North Wales. Forestry 64 (3): 289 - 301 doi: 10.1093/forestry/64.3.289

Geelhoed, J.S., Van Riemsdijk, W.H., and Findeneggm G. 1997. Effects of sulphate and pH on the plant-availability of phosphate adsorbed on goethite. Plant and Soil. 197: 241 - 249 doi: 10.1023/A:1004228715984 
439 Giesler, R., Andersson, T., Lovgren, L., and Persson, P. 2005. Phosphate sorption in aluminium and $440 \quad$ iron-rich humus soils. Soil Science Society of America 69: 77-86 doi: 10.2136/sssaj2005.0077

441 Hartmann, D., Klein Tank, A.M.G., and Rusticucci, M. 2013. Observations: Atmosphere and Surface in 442 [Stocker, T.F., Qin, D., Plattner, G., Tignor, M.M.B., Allen, S.K., Boschung, J., Nauels, A., Xia, Y.,

Heathwaite, A. L., and Dils, R. M. 2000. Characterising phosphorus loss in surface and subsurface hydrological pathways. Science of the Total Environment. 25, 523-538 doi: 10.1016/S00489697(00)00393-4

Huser, B.J., and Rydin, E. 2005. Phosphorus inactivation by aluminium in Lakes Gardsjön and Härsvatten sediment during the industrial acidification period in Sweden. Canadian Journal of Fisheries and Aquatic Sciences 62: 1702-1709 doi: 10.1139/f05-083

Jarvie, H.P., Sharpley, A.N., Spears, B., Buda, A.R., May, L., and Kleinman, P.J.A. 2013. Water quality remediation faces unprecedented challenges from "Legacy Phosphorus". Environmental Science and Technology 47: 8997 - 8998 doi: 10.1021/es403160a

Jensen, M.B., Hansen, H.C.B., Nielsen, N.E., and Magid, J. 1999. Phosphate leaching from intact soil column in response to reducing conditions. Water Air and Soil Pollution 113: 411 - 423 doi: 10.1023/A:1005092704105 
461

462

463

464

465

466

467

468

469

470

471

472

473

474

475

476

477

478

479

480

481
Jeppesen, E., Jensen, J.P., Sondergaard, M., and Lauridsen, T.I. 2005. Response of fish and plankton to nutrient loading reduction in eight shallow Danish lakes with special emphasis on seasonal dynamics. Journal of Freshwater Biology 50: 1616 - 1627 doi: 10.1111/j.13652427.2005.01413.x

Jeziorski, A., Yan, N. D., Paterson, A. M., DeSellas, A. M., Turner, M. A., Jeffries, D. S., Keller, B., Weeber, R.C., McNicol, D.K., Palmer, M.E., Mclver, K., Arseneau, K., Ginn, B.K., Cumming, B.F., and Smol, J. P. 2008. The widespread threat of calcium decline in fresh waters. Science, 322 (5906): 1374-1377. doi:10.1126/science.1164949

Jorgensen, J.R., Wells, C.G., and Metz, L.J. 1975. The nutrient cycle: key to continuous forest production. Journal of Forestry. 73 (7): 400-403

Kirkwood, D.E. and Nesbitt, H.W. 1991. Formation and evolution of soils from an acidified watershed: Plastic Lake, Ontario, Canada. Geochimica et Cosmochimica Acta, 55 (5): 1295 - 1308 doi: 10.1016/0016-7037(91)90308-R

Knops, J.M.H., Wedin, D.A., and Naeem, S. 2010. The role of litter quality feedback in terrestrial nitrogen and phosphorus cycling. The Open Ecology Journal 3: 14-25

Koski-Vähälä, J. 2001. Role of resuspension and silicate in internal phosphorus loading. Dissertation in Limnology, Department of Limnology and Environmental Protection, Department of Applied Chemistry and Microbiology, University of Helskini, Helsinki,

Moore, R.D. and Wondzell., S.M. 2005. Physical hydrology and the effects of forest harvesting in the pacific northwest: a review. Journal of the American Water Resources Association 41 (4): 763 $-784$ 
482

483

484

485

486

487

488

489

490

491

492

493

494

495

496

497

498

499

500

501

502

Nziguheba, G., Palm, C.A., Buresh, R.J., and Smithson, P.C. 1998. Soil phosphorus fractions and adsorption as affected by organic and inorganic sources. Plant and Soil 198: 159 - 168 doi: 10.1023/A:1004389704235

O'Brien, H., Eimers, M.C., Watmough, S.A., and Casson, N.J. 2013. Spatial and temporal patterns in total phosphorus in south-central Ontario streams: the role of wetlands and past disturbance. Canadian Journal of Fisheries and Aquatic Sciences 70: 766 - 774 doi: 10.1139/cjfas-2012-0474

O'Connor, E.M., Dillon, P.J., Molot, L.A., and Creed, I.F. 2009. Modelling dissolved organic carbon mass balances for lakes of the Muskoka River Watershed. Hydrology Research. 40 (2-3): 273 - 290 doi: 10.2166/nh.2009.106

Oni, S.K., Tiwari, T., Ledesma, J.L., Ågren, A.M., Teutschbein, C., Schelker, J., Laudon, H., and Futter, M.N. 2015. Local and landscape-scale impacts of clear-cuts and climate change on surface water dissolved organic carbon in boreal forests. Journal of Geophysical Research: Biogeosciences. 120, doi: 10.1002/2015JG003190.

Ontario Ministry of Natural Resources. 2007. Ecological Land Classification of Ontario, available for download at: https://www.javacoeapp.Irc.gov.on.ca/geonetwork/srv/en/main.home (last access:15 January 2014)

Palmer, M.E., Norman, D.Y., Paterson, A.M, and Girard, R.E. 2011. Water quality changes in southcentral Ontario lakes and the role of local factors in regulating lake response to regional stressors. Canadian Journal of Fisheries and Aquatic Sciences 68: 1038-1050 doi: $10.1139 /$ f2011-041 
Paterson, A.M., Cumming, B.F., Smol, J.P., and Hall, R.I. 2004. Marked recent increases in colonial scaled chrysophytes in Boreal lakes: implications for the management of taste and odour events. Journal of Freshwater Biology. 49: 199 - 207 doi: 10.1046/j.136502427.2003.01170.x

Peltovuori, T. 2006. Phosphorus in agricultural soils of Finland - characterization of reserves and retention in mineral soil profiles, Pro Terra No. 26, Academic dissertation, University of Helsinki, Helsinki.

Pinder, K.C., Eimers, M.C., and Watmough, S.A. 2014. Impact of wetland disturbance on phosphorus loadings to lakes. Canadian Journal of Fisheries and Aquatic Sciences. 71(11): 1695 - 1703 doi: 10.1139/cjfas-2014-0143

Piirainen, S., Finer, L., Mannerkoski, H., and Starr, M. 2004. Effects of forest clear-cutting on the sulphur, phosphorus and base cations fluxes through podzolic horizons. Biogeochemistry 69: 405-424. Doi: 10.1023/B:IOG.0000031061.80421.1b

Racey, G.D., and Euler, D.L. 1981. Small mammal and habitat response to shoreline cottage development in central Ontario. Canadian Journal of Zoology 60: 865-880 doi: 10.1139/z82119

Richardson, C.J. 1985. Mechanisms controlling phosphorus retention capacity in freshwater wetlands. Science. 228 (4706): 1424 - 1427

Saelthun, N. 1995. Nordic HBV Model, Norwegian Water Resources and Energy, Administration, Oslo, Norway, 1995.

Shafqat, M.N. and Pierzynski, G.M. 2014. The freudlich adsorption isotherm constants and prediction of phosphorus bioavailability as affected by different phosphorus sources in two Kansas soils Chemosphere 90: 72 - 80 doi:10.1016/j/chemosphere.2013.10.009 
Sharpley, A., Kleinman, P.J.A., McDowell, R.W., Gitau, M., and Bryant, R.B. 2002. Modeling phosphorus transport in agricultural watersheds: processes and possibilities. Journal of Soil and Water Conservation 57 (6): 425 - 439

Sharpley, A., Jarvie, H.P., Buda, A., May, L., Spears, B. and Kleinman, P. 2013. Phosphorus legacy: overcoming the effects of past management practices to mitigate future water quality impairment. Journal of Environmental Quality. 25: 1308 - 1326 doi: $10.2134 /$ jeq2013.03.0098

Väänänen, R. 2008. Phosphorus retention in forest soils and the functioning of buffer zones used in forestry, Dissertationes Forestales 60, Department of Forest Ecology, University of Helsinki, Helsinki, p. 42.

Väänänen, R., Kenttämies, K., Nieminen, M., and Ilvesniemi, H. 2007. Phosphorus retention properties of forest humus layer in buffer zones and clear-cut areas in southern Finland. Boreal Environment Research 12: 601-609

Watmough, S.A., and Aherne, J. 2008. Estimating calcium weathering rates and future lake calcium concentrations in the Muskoka-Haliburton region of Ontario Canadian Journal of Fisheries and Aquatic Sciences 65 (5): $821-833$ doi: 10.1139/f07-196

Watmough, S.A. and Dillon, P.J. 2003a. Base Cation and nitrogen budgets for a mixed hardwood catchment in south-central Ontario. Ecosystems. 6:675 - 693 doi: 10.1007/s10021-002-0164y

Watmough, S.A., and Dillon, P.J. 2003b. Base cation and nitrogen budgets for seven forested catchments in central Ontario, 1983-1999. Forest Ecology and Management. 177: 155-177 doi: $10.1016 / \mathrm{S0378-1127(02)00320-1}$ 
547 Whitehead, P. G., Jin, L., Baulch, H. M., Butterfield, D., Oni, S. K., Dillon, P. J., Futter, M., Wade, A. J.,

548 North, R., O’Connor, E. M.. and Jarvie, H. P. 2011. Modelling phosphorus dynamics in

549 multibranch river systems: a study of the Black River, Lake Simcoe, Ontario, Canada, Science

550 of the Total Environment., 412-413: 315-323 doi: 10.1016/j.scitotenv.2011.09.073

551

552

553

554

555

556

557

558

559

560

561

562

563

564

565 
566 Tables:

567

568

569

570

571

572

\begin{tabular}{ccccc}
\hline & Characteristics & Dickie & Harp & Plastic \\
\hline Catchment area (ha) & 500 & 542 & 127 \\
Lake area (ha) & 93.6 & 71.4 & 32.1 \\
& Lake depth (m) & 5.0 & 13.3 & 7.9 \\
Mean lake TP (ug/l) & 10.2 & 7.1 & 5.6 \\
\hline \multirow{4}{*}{ Landuse } & Wetland & 9.3 & 10 & 1.6 \\
& Coniferous Forest & 62.3 & 57.1 & 74.2 \\
& Deciduous Forest & 2.4 & 3.5 & 7.1 \\
& Disturbed & 1.5 & 4.3 & 1.5 \\
& Residential (cottages) & 5.5 & 4.4 & 0 \\
& Open Water & 18.9 & 20.8 & 15.6
\end{tabular}

573 Table 1: Study site characteristics (catchment and landuse data derived from Ontario Ministry of

574 Environment Ecological Classification of Ontario (2007); residential data from Dillon and Molot (1996)

575

576

577

578

579

580

581

582

583 


\begin{tabular}{lcccc}
\hline \multirow{2}{*}{ Soil Type } & Model Parameter & \multicolumn{3}{c}{ Catchment } \\
& Dickie & Harp & Plastic \\
\hline \multirow{3}{*}{ Un- disturbed } & $\mathrm{EPC}_{0}(\mu \mathrm{g} \mathrm{P} / \mathrm{l})$ & $1.00 \mathrm{E} 1$ & $1.00 \mathrm{E} 1$ & $1.00 \mathrm{E} 1$ \\
& Plant Uptake $(\mathrm{kg} / \mathrm{ha} / \mathrm{year})$ & 0.05 & 0.19 & 0.18 \\
\hline \multirow{3}{*}{ Disturbed } & P inputs to soils $(\mathrm{kg} / \mathrm{ha} / \mathrm{yr})$ & 0.68 & 0.22 & 0.19 \\
& $\mathrm{EPC}_{0}(\mu \mathrm{g} \mathrm{P} / \mathrm{l})$ & $1.50 \mathrm{E} 3$ & $6.00 \mathrm{E} 2$ & $2.00 \mathrm{E} 2$ \\
& Plant Uptake $(\mathrm{kg} / \mathrm{ha} / \mathrm{year})$ & 0.02 & 0.09 & 0.17 \\
\hline
\end{tabular}

Table 2: Comparison of soil parameters between disturbed and undisturbed areas in INCA model, for wetlands (Dickie) and forests (Harp and Plastic).

591 
602

603

604

605

\begin{tabular}{cccc}
\hline & \multicolumn{3}{c}{ Seasonal \% Lake P retention } \\
& Dickie & Harp & Plastic \\
\hline Spring & 25.4 & 62.0 & 52.4 \\
Summer & 94.4 & 80.9 & 92.8 \\
Autumn & 22.6 & 66.9 & 73.5 \\
Winter & 67.4 & 77.8 & 75.8
\end{tabular}

606 Table 3: Seasonal variability of Lake \% TP retention (modelled using INCA-P)

607

608

609

610

611

612

613

614

615

616

617

618

619 
620 Figures:

621 Figure 1: Study site schematic demonstrating sub-catchments as used in the INCA-P model

622 application

623 Figure 2: Comparison of seasonal and annual model performance across all streams (lake inflows)

624 and lake outflows, demonstrating a) $R^{2}$ and b) model average error (MAE) over 2001-2007

625 calibration period.

626 Figure 3: Model performance at a range of streams (lake inflows) over entire period of record (1978-

627 2007) demonstrating capacity of meteorology to account for inter-annual variability in P fluxes

628 Figure 4: comparison of inter-annual model performance across all streams (lake inflows) and lake

629 outflows, using a) $R^{2}$ and b) MAE, with and without inclusion of disturbance landuse classes.

630 Figure 5: Model hindcast at a range of streams (lake inflows) (1978-2007) demonstrating

631 improvement in model performance through inclusion of disturbance class (thick black line)

632 Figure 6: Sources of $\mathrm{P}$ soil exports by landuse class, comparing annual fluxes of $\mathrm{P}$ with precipitation

633 Figure 7: Range of total phosphorus retention (\%TPR) across subcatchments within Dickie, Harp and

634 Plastic, calculated from modelled values over 1978-2007 


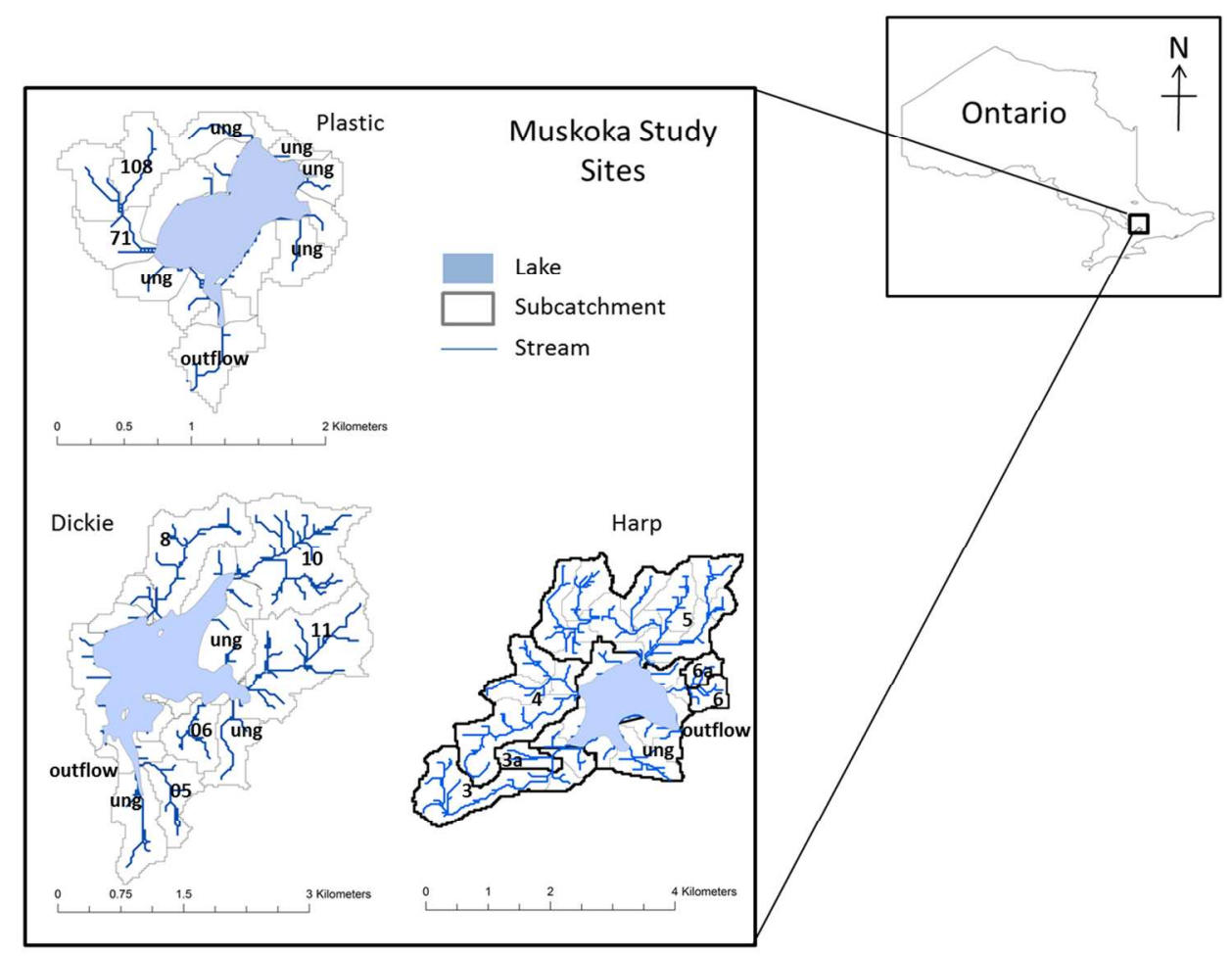

Figure 1: Study site schematic demonstrating sub-catchments as used in the INCA-P model application $254 \times 190 \mathrm{~mm}(150 \times 150 \mathrm{DPI})$ 

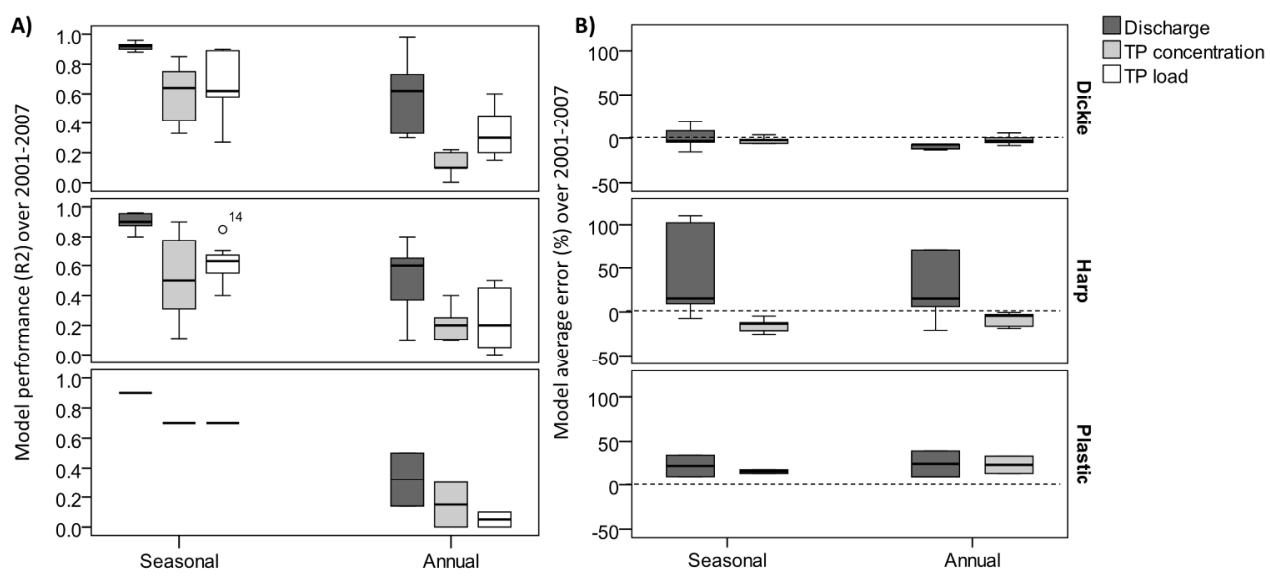

Figure 2: Comparison of seasonal and annual model performance across all streams (lake inflows) and lake outflows, demonstrating a) $R^{2}$ and b) model average error (MAE) over 2001-2007 calibration period. $385 \times 176 \mathrm{~mm}(150 \times 150 \mathrm{DPI})$ 

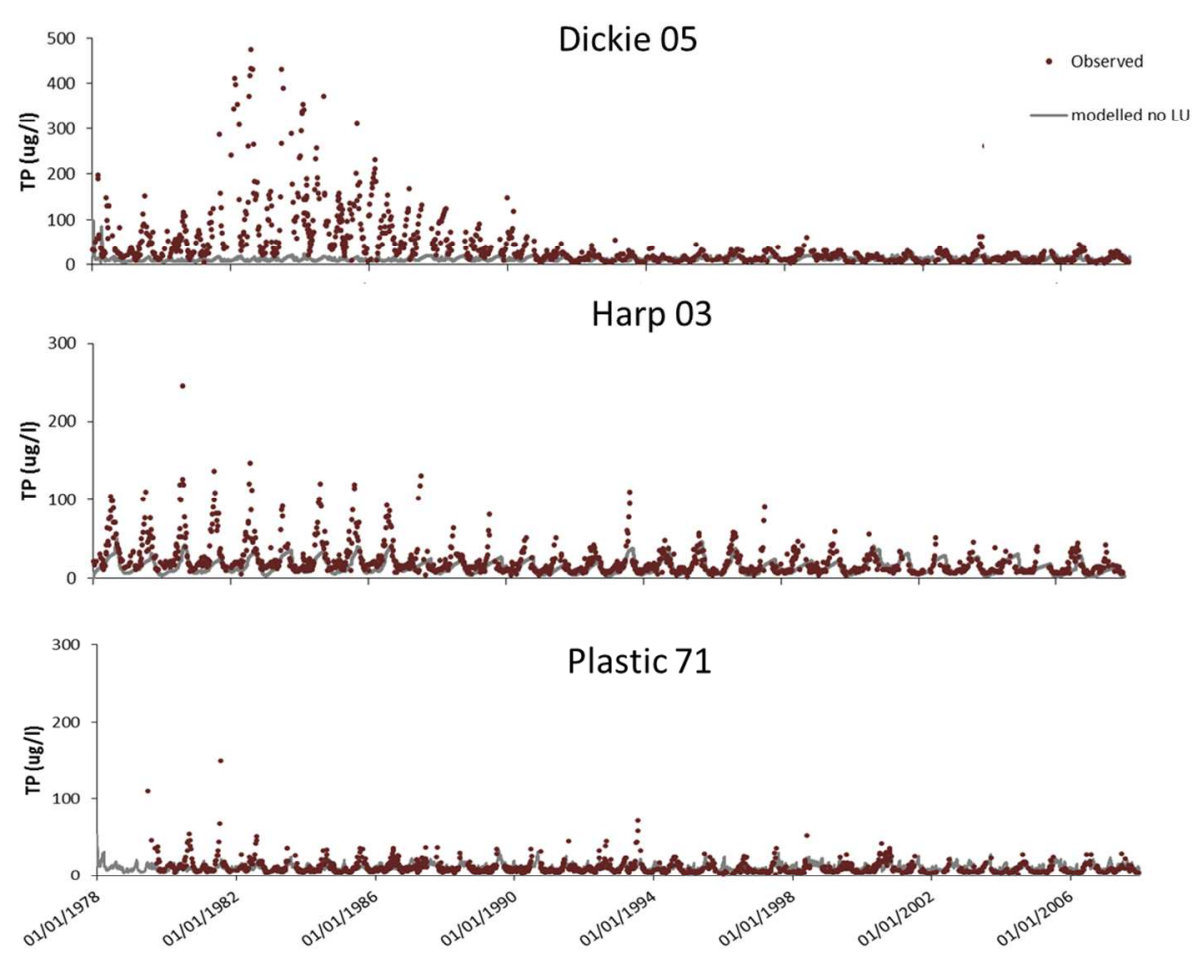

Figure 3: Model performance at a range of streams (lake inflows) over entire period of record (1978-2007) demonstrating capacity of meteorology to account for inter-annual variability in $\mathrm{P}$ fluxes $217 \times 168 \mathrm{~mm}$ (150 x $150 \mathrm{DPI})$ 

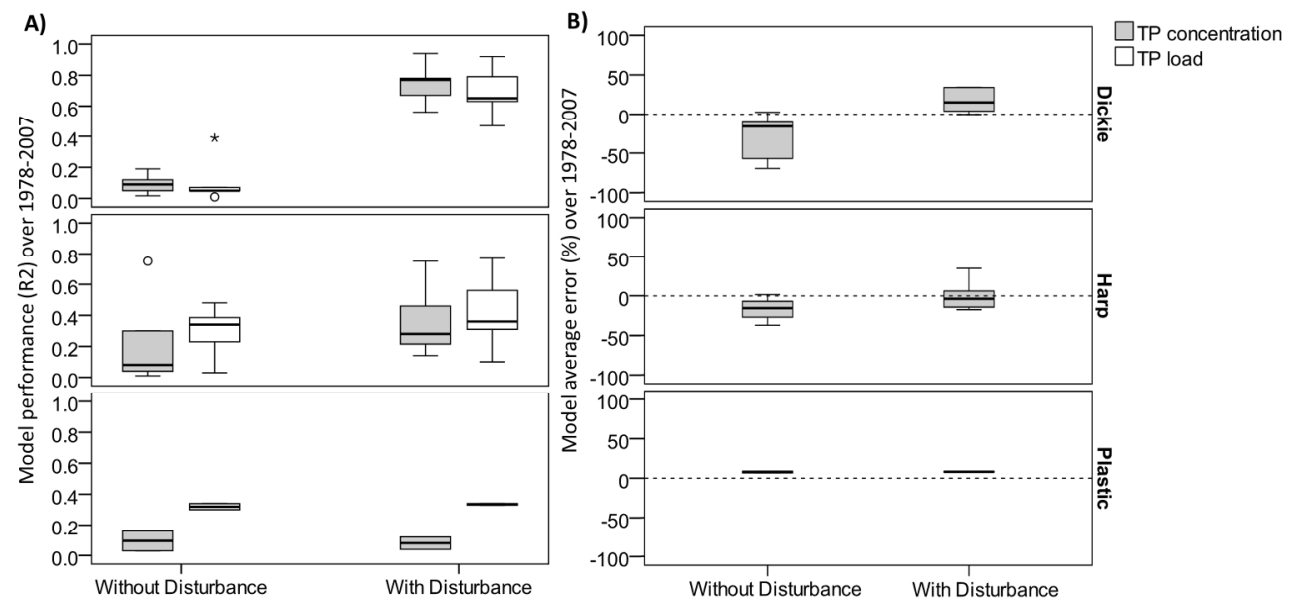

Figure 4: Comparison of inter-annual model performance across all streams (lake inflows) and lake outflows, using a) $R^{2}$ and b) $M A E$, with and without inclusion of disturbance landuse classes. 


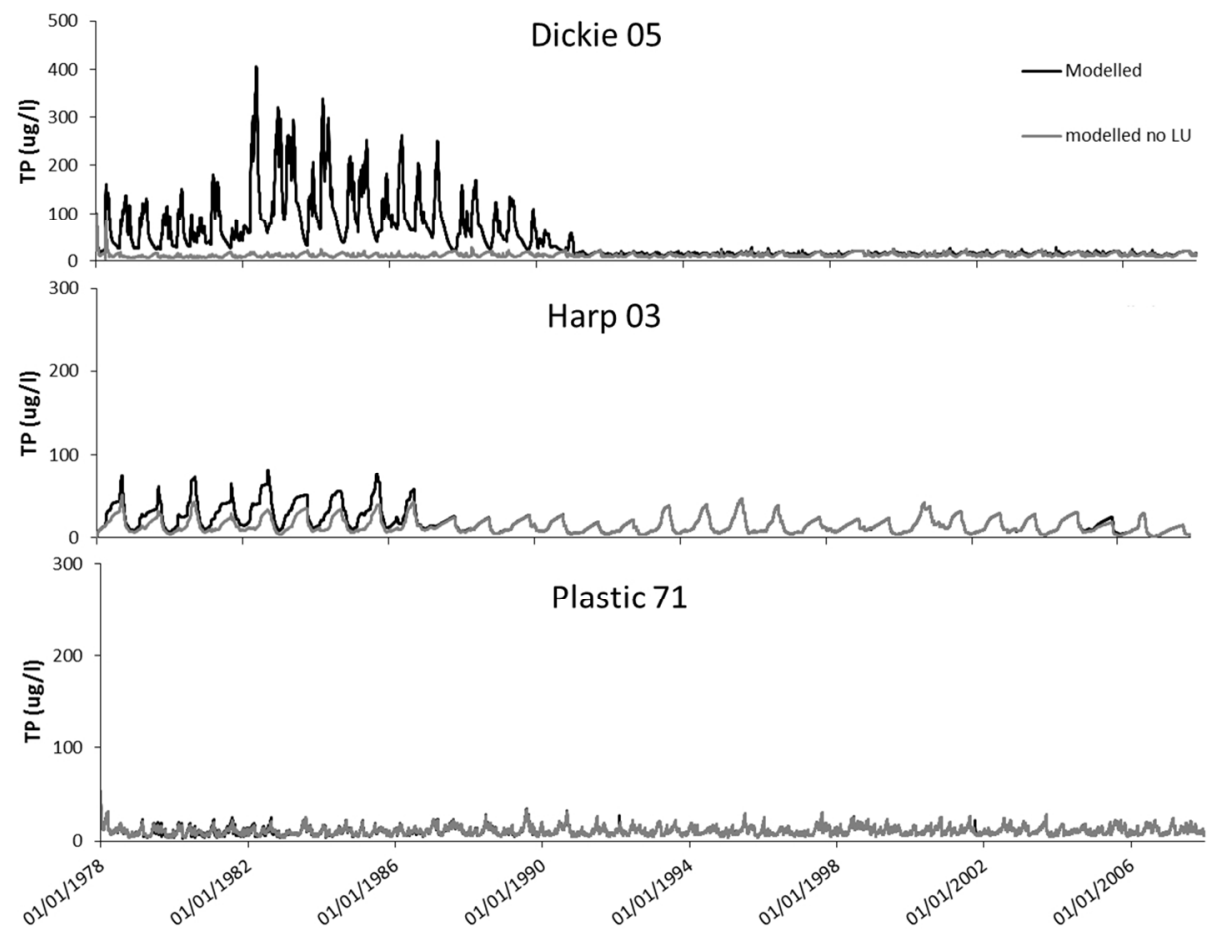

Figure 5: Model hindcast at a range of streams (lake inflows) (1978-2007) demonstrating improvement in model performance through inclusion of disturbance class (thick black line) 


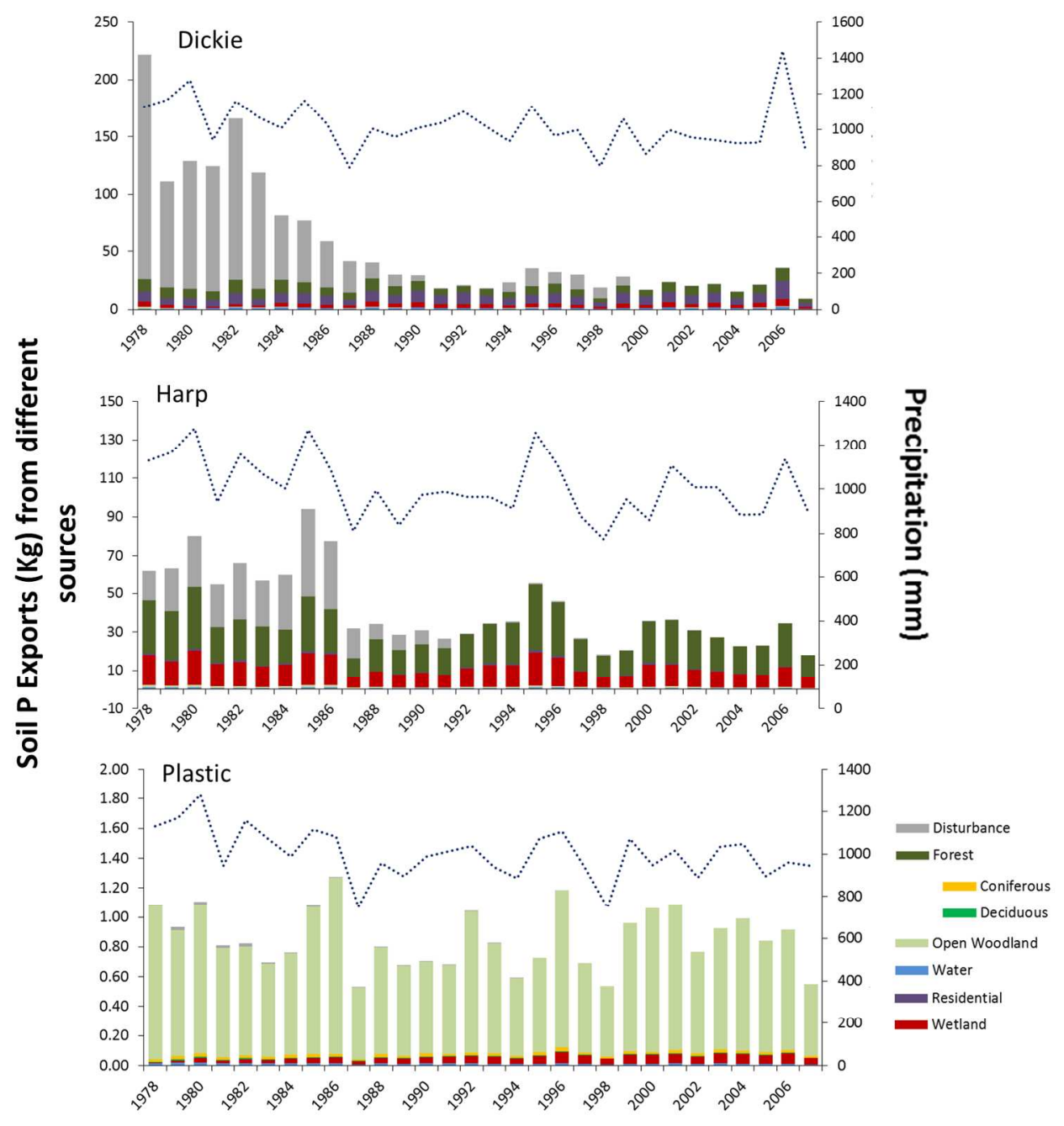

Figure 6: Sources of $\mathrm{P}$ soil exports by landuse class, comparing annual fluxes of $\mathrm{P}$ with precipitation $292 \times 303 \mathrm{~mm}(150 \times 150 \mathrm{DPI})$ 


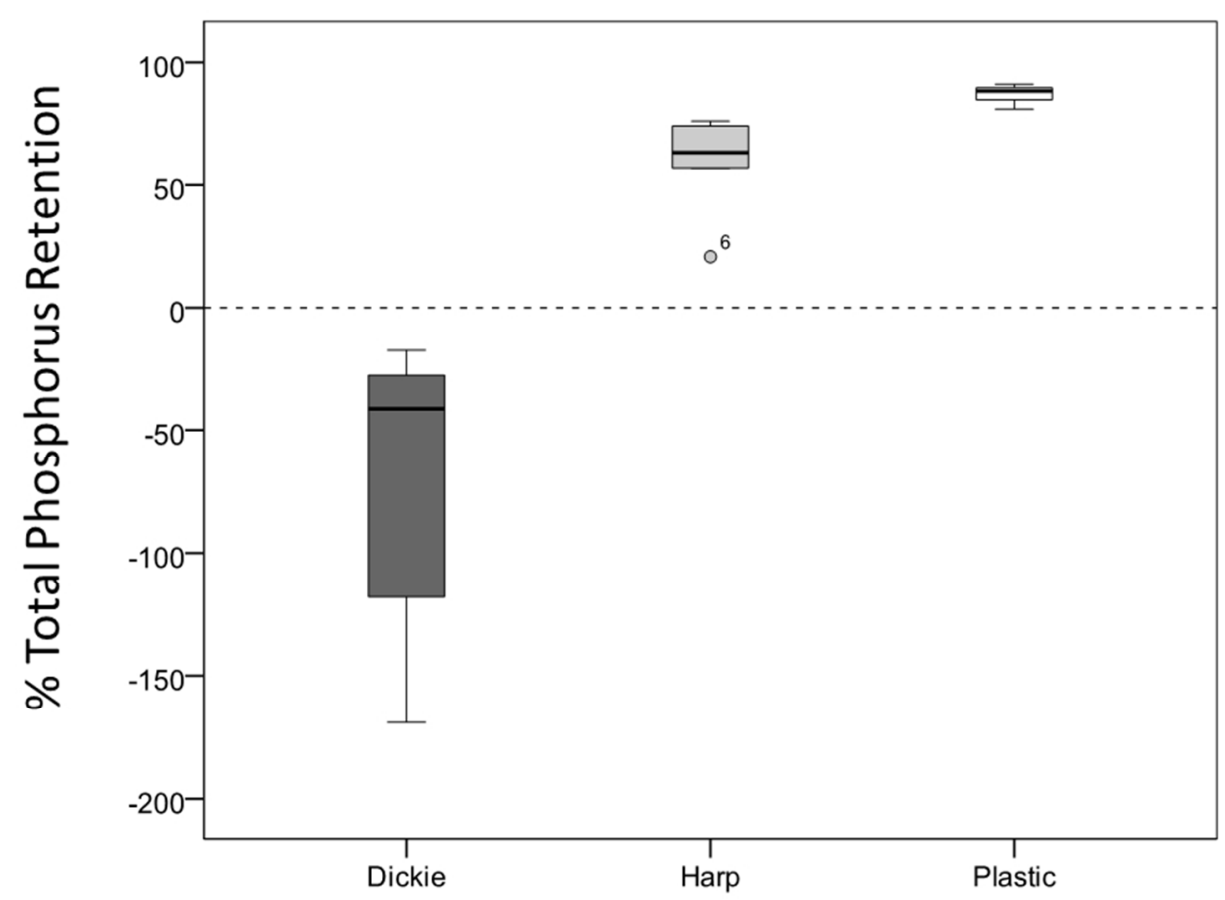

Figure 7: Range of total phosphorus retention (\%TPR) across subcatchments within Dickie, Harp and Plastic, calculated from modelled values over 1978-2007 $161 \times 123 \mathrm{~mm}(150 \times 150 \mathrm{DPI})$ 